\title{
Incidence and impact of totally occluded culprit coronary artery in patients with non- ST segment elevation myocardial infarction acute coronary syndrome
}

Sherif W. Ayad*i(D, Tarek H. El Zawawy, Mohamed I. Lotfy, Ahmed M. Naguib and Ahmed M. El Amrawy

\begin{abstract}
Background: Significance of totally occluded culprit coronary artery in patients presenting with non-ST segment elevation myocardial infarction (NSTEMI) is underestimated. The aim of the study was to evaluate the incidence and impact of totally occluded culprit artery on in-hospital and 6 months follow-up outcomes of NSTEMI acute coronary syndrome (ACS) patients.

Results: We collected retrospectively data of 500 NSTEMI patients who presented to our hospital from June 2016 to June 2017. All patients underwent PCl within $72 \mathrm{~h}$ of presentation. We excluded patients with cardiogenic shock, prior CABG, and STEMI. Patients were divided into two groups according to pre-procedural culprit vessel thrombolysis in myocardial infarction (TIMI) flow. Group 1, TIMI flow 0 total coronary occlusion, included 112 patients (22.4\%). Group 2, TIMI flow 1-3 non-total occlusion, included 388 patients (77.6\%). Group 1 patients had significantly higher incidence of smoking $(p=0.01)$, significantly higher level of cardiac enzymes $(p<0.001)$, significantly more collaterals $(p<0.001)$, and significantly more LCX and RCA as the culprit vessel $(p<0.01)$, while group 2 patients had significantly higher incidence of diabetes $(p=0.02)$ and significantly more LAD as the culprit vessel. There were no significant differences between the two groups regarding the major adverse cardiac and cerebrovascular events (MACCE) in-hospital (5.3\% in totally occluded group vs. $1 \%$ in non-totally occluded group, $p=0.07$ ), but group 1 patients had significantly higher incidence of in-hospital arrhythmia (8.9\% in group 1 vs. 1\% in group 2, $p=0.007)$. After 6 months follow-up, there were no significant differences regarding MACCE between the 2 groups after 6 months follow-up (5.4\% in group 1 vs. 4.6\% of group 2, $P=0.24)$.
\end{abstract}

Conclusion: $22.4 \%$ of NSTEMI patients have a totally occluded culprit artery. The presence of an occluded culprit artery did not significantly affect the clinical outcomes of NSTEMI patients either in-hospital or after 6 months follow-up but was associated with significantly higher incidence of in-hospital arrhythmia.

Keywords: Non-ST segment elevation myocardial infarction, Coronary total occlusion, Electrocardiography

\footnotetext{
* Correspondence: sherifwagdyayad@yahoo.com

Department of Cardiology, Faculty of Medicine, Alexandria University, Alexandria, Egypt
}

\section{Springer Open}

(c) The Author(s). 2021 Open Access This article is licensed under a Creative Commons Attribution 4.0 International License, which permits use, sharing, adaptation, distribution and reproduction in any medium or format, as long as you give appropriate credit to the original author(s) and the source, provide a link to the Creative Commons licence, and indicate if changes were made. The images or other third party material in this article are included in the article's Creative Commons licence, unless indicated otherwise in a credit line to the material. If material is not included in the article's Creative Commons licence and your intended use is not permitted by statutory regulation or exceeds the permitted use, you will need to obtain permission directly from the copyright holder. To view a copy of this licence, visit http://creativecommons.org/licenses/by/4.0/. 


\section{Background}

The spectrum of acute coronary syndrome (ACS) including ST-segment elevation myocardial infarction (STEMI), non-ST segment elevation myocardial infarction (NSTEMI), and unstable angina have become the leading cause of death globally [1-3].

In the Middle East including Egypt, 64\% of ACS patients present with NSTEMI and $36 \%$ present with STEMI according to the results of the ACCESS registry [4].

Recent studies have shown that the incidence of NSTE MI has slightly increased over the last decade and have lower short-term mortality compared with STEMI patients, while at 1 or 2 years follow-up mortality rates become higher [5].

Based on electrocardiogram (ECG), ACS patients can be divided into STEMI patients with ST-segment elevation on ECG denoting total or near total occlusion of the culprit artery and necessitating immediate coronary angiography and revascularization or NSTEMI patients with ST-segment depression or T-wave inversion on ECG with early angiography and revascularization only if they have high risk [6,7].

Previous studies have shown that nearly $25 \%$ of NSTE MI patients present with a totally occluded coronary artery, and two-thirds of the occlusions are already collateralized at the time of angiographic examination [8, 9]; this was more common in patients presenting with either right coronary artery (RCA) or left circumflex artery (LCX) involvement [8-14], which could be explained by the lack of ECG sensitivity in detecting acute ischemia in the inferolateral and posterior walls.

The lack of classic ST-segment elevation on ECG in these subset of NSTEMI patients, despite the presence of totally occluded culprit artery, lead to either delay in or no revascularization [15].

Currently, the impact of totally occluded artery on the outcome of NSTEMI patients is still unclear, as previous studies had reported contradictory results. Some studies reported worse outcome for patients with totally occluded culprit artery $[9,13,16]$ while other studies reported no significant difference in outcome $[8,10,11,17]$.

In this study, we aimed to evaluate the incidence and impact of totally occluded culprit artery on in-hospital and after 6 months follow-up outcomes of NSTEMI patients.

\section{Methods}

\section{Study design}

This is a retrospective observational study conducted on consecutive NSTEMI patients who presented to our hospital between 1 June 2016 and 1 June 2017.
The inclusion criteria were established diagnosis of NSTEMI (patients with acute chest pain but no persistent ST-segment elevation, ECG changes may include transient ST-segment elevation, persistent or transient ST-segment depression, $\mathrm{T}$-wave inversion, flat $\mathrm{T}$ waves, pseudo-normalization of $\mathrm{T}$ waves or the ECG may be normal with elevated cardiac biomarkers) and fulfilling guideline recommendation for PCI treatment [7] with invasive strategy performed within $72 \mathrm{~h}$ of admission. The exclusion criteria were previous CABG, cardiogenic shock, previous PCI of same culprit vessel, STEMI, and left main coronary artery disease. The study population included 500 patients. This is an all-comer study, and therefore, a formal sample size calculation was not required.

\section{Data collection}

All patients' demographic data were collected including age, gender, comorbidities (hypertension, diabetes, dyslipidemia, prior ACS or PCI), and smoking.

From laboratory data, we registered troponin I, creatine kinase $\mathrm{MB}$ fraction $(\mathrm{CK}-\mathrm{MB})$, urea, and creatinine levels on admission and peak levels during the hospital stay.

ECG and echocardiographic data including ejection fraction (EF), wall motion abnormalities (WMA), and degree of mitral regurgitation (MR) were also registered.

Among in-hospital treatments, we registered PCI procedure details including access site, procedure outcomes, complications, and the use of antithrombotic therapy (acetyl salicylic acid, clopidogrel, ticagrelor, heparin, enoxaparin, and glycoprotein IIb/IIIa inhibitors).

The culprit artery was identified primarily on angiographic findings with ECG and echocardiogram to support the assessment if needed. Totally occluded artery was defined as a lesion with $100 \%$ stenosis and a thrombolysis in myocardial infarction (TIMI) flow 0 [18].

Baseline and at hospital discharge GRACE and TIMI risk scores were calculated [19, 20].

Baseline syntax score and residual syntax score were also calculated [21].

\section{Clinical endpoint measurements}

The primary clinical outcomes of the study were MACCE which was defined as a composite of death, reinfarction, need for revascularization, heart failure, and cerebrovascular stroke either in-hospital or after 6 months follow-up.

\section{Statistical analysis}

Data were analyzed using the Statistical Package for Social Sciences (SPSS ver.20 Chicago, IL, USA) [22]. K-S test of normality was done to check for normality of 
quantitative variables. Normally distributed data were described using mean and standard deviation, while not normally distributed data were described using median and range, and non-parametric tests were applied. We used number and percent to describe qualitative data. Independent Student $t$-test was used to compare age between the 2 groups. Mann-Whitney $U$ test was used to compare non-parametric quantitative parameters between the 2 groups. Pearson Chi square was used to compare $2 \times 2$ categorical variables, and Fisher's exact test if $>20 \%$ of cells had expected cell count less than 5 . And in $>2 \times 2$ table, we used Monte Carlo significance test if $>20 \%$ of cells had expected cell count less than 5 . Kaplan-Meier survival curve was done for survival analysis of MACCE occurrence, with duration in days till occurrence; Log rank test used was to compare survival between the 2 groups. Any test was considered significant below or equal to 0.05 .
An informed consent was obtained from every patient or the legal guardians. The study was approved by the local ethics committee.

\section{Results}

\section{Patient characteristics}

The study population included 500 patients who were classified into two groups:

Group 1 included 112 patients with totally occluded culprit vessel.

Group 2 included 388 patients with non-totally occluded culprit vessel.

Both patient groups (1 and 2) were well matched with respect to demographic data and clinical characteristics with no significant difference between them except for smoking which was significantly higher in group 1

Table 1 Baseline characteristics of the studied populations

\begin{tabular}{|c|c|c|c|c|c|c|}
\hline & \multicolumn{2}{|c|}{ Group $1(n=112)$} & \multicolumn{2}{|c|}{ Group $2(n=388)$} & Total sample & Test value $(p)$ \\
\hline \multicolumn{7}{|l|}{ Age } \\
\hline Mean \pm SD (years) & \multicolumn{2}{|c|}{$56.54 \pm 9.437$} & \multicolumn{2}{|c|}{$59.09 \pm 9.686$} & $57.53 \pm 9.57$ & $p=0.08$ \\
\hline \multicolumn{7}{|l|}{ Sex } \\
\hline Male & 98 & $87.5 \%$ & 302 & $77.8 \%$ & 400 (80\%) & \multirow[t]{2}{*}{$p=0.11$} \\
\hline Female & 14 & $12.5 \%$ & 86 & $22.2 \%$ & $100(20 \%)$ & \\
\hline \multicolumn{7}{|l|}{ DM } \\
\hline Insulin treated & 8 & $7.14 \%$ & 30 & $7.74 \%$ & \multirow[t]{2}{*}{$228(45.6 \%)$} & \multirow[t]{2}{*}{${ }^{*} \mathrm{FE}_{p}=0.02$} \\
\hline Orally treated & 28 & $25 \%$ & 162 & $41.7 \%$ & & \\
\hline HTN & 56 & $50 \%$ & 244 & $62.9 \%$ & 300 (60\%) & $p=0.08$ \\
\hline \multicolumn{7}{|l|}{ Smoker } \\
\hline Current smoker & 62 & $55.3 \%$ & 172 & $44.3 \%$ & $234(46.8 \%)$ & \multirow[t]{2}{*}{${ }^{*}{ }^{\mathrm{FE}} p=0.01$} \\
\hline Former smoker & 18 & $16.1 \%$ & 30 & $7 \%$ & $48(9.6 \%)$ & \\
\hline Dyslipidemia & 44 & $39.3 \%$ & 120 & $30.9 \%$ & $164(32.8 \%)$ & $p=0.24$ \\
\hline CKD & 4 & $3.6 \%$ & 36 & $9.3 \%$ & $40(8 \%)$ & $p=0.262$ \\
\hline FH of CAD & 24 & $21 \%$ & 70 & $18 \%$ & 94 (18.8\%) & $p=0.56$ \\
\hline Hx of ACS & 4 & $3.6 \%$ & 32 & $8.2 \%$ & $36(7.2 \%)$ & $p=0.378$ \\
\hline \multirow[t]{2}{*}{$\mathrm{Hx}$ of $\mathrm{PCl}$} & 8 & $7.1 \%$ & 56 & $14.4 \%$ & $64(12.8 \%)$ & $p=0.15$ \\
\hline & \multicolumn{2}{|c|}{ Group $1(n=112)$} & & \multicolumn{2}{|c|}{ Group 2 ( $n=388)$} & $p$ \\
\hline \multicolumn{7}{|l|}{ Admission to $\mathrm{PCl}$} \\
\hline Min.-Max. (h) & \multicolumn{2}{|c|}{$12-72$} & & \multicolumn{2}{|l|}{$12-72$} & \multirow[t]{3}{*}{$\mathrm{MW}_{p}=0.35$} \\
\hline Mean \pm SD. (h) & \multicolumn{2}{|c|}{$27.11 \pm 10.651$} & & \multicolumn{2}{|c|}{$28.73 \pm 11.956$} & \\
\hline Median (h) & \multicolumn{2}{|l|}{24} & & \multicolumn{2}{|l|}{24} & \\
\hline \multicolumn{7}{|l|}{ Killip class } \\
\hline 1 & \multicolumn{2}{|l|}{102} & $91.07 \%$ & 362 & $93.3 \%$ & \multirow[t]{3}{*}{$\mathrm{MW}_{p=0.77}$} \\
\hline II & \multicolumn{2}{|l|}{6} & $5.4 \%$ & 18 & $4.6 \%$ & \\
\hline III & \multicolumn{2}{|l|}{4} & $3.6 \%$ & 8 & $2.1 \%$ & \\
\hline
\end{tabular}

$x^{2}$ value for Chi square, $t$ Student $t$-test, $M W$ Mann-Whitney test, FEP Fisher's exact significance ${ }^{*}$ Statistically significant at $p \leq 0.05$ 
(55.3\% vs. $44.3 \%, p=0.01)$ and diabetes mellitus (DM) which was significantly higher in group 2 (25\% vs. $41.7 \%$, $p=0.02$ ). Regarding the mean time from admission to PCI, there was no statistically significant difference between the two groups $(27.11 \pm 10.6 \mathrm{~h}$ vs. $28.7 \pm 11.9 \mathrm{~h}$, $p=0.35)$. The baseline characteristics of both groups are presented in Table 1.

\section{ECG, echocardiography, and laboratory results}

$\mathrm{CK}-\mathrm{MB}$ and troponin I levels were significantly higher in group 1 than in group 2 (92 vs. 35ng/ml, $p<0.001$ and
7.5 vs. $1.5 \mathrm{ng} / \mathrm{ml}, p<0.001)$. There was no significant difference between the two groups regarding other laboratory, ECG, and echocardiography results. The baseline ECG, echocardiography, and laboratory results of both groups are presented in Table 2.

\section{GRACE risk score and TIMI risk score}

There were no statistically significant differences between the two groups as regard the GRACE risk score at admission or TIMI risk score at admission (Table 3).

Table 2 Baseline ECG, echocardiography, and laboratory results of both groups

\begin{tabular}{|c|c|c|c|c|c|}
\hline & \multicolumn{2}{|c|}{ Group $1(n=112)$} & \multicolumn{2}{|c|}{ Group $2(n=388)$} & \multirow[t]{2}{*}{$p$} \\
\hline & No. & $\%$ & No. & $\%$ & \\
\hline \multicolumn{6}{|l|}{ Initial ECG } \\
\hline Normal & 64 & 57.1 & 238 & 61.3 & $p=0.434$ \\
\hline ST depression & 30 & 26.8 & 66 & 17.0 & $p=0.102$ \\
\hline T-wave inversion & 8 & 12.5 & 56 & 14.4 & $p=0.7$ \\
\hline Q waves & 2 & 1.8 & 22 & 5.7 & $p=0.3$ \\
\hline Bundle branch & 2 & 1.8 & 6 & 1.5 & $p=1$ \\
\hline \multicolumn{6}{|l|}{$\mathrm{Hb}$} \\
\hline Min.-Max. (g/dl) & \multicolumn{2}{|l|}{$9.0-15.0$} & \multicolumn{2}{|l|}{$11.0-16.0$} & \multirow[t]{3}{*}{${ }^{t} p=0.697$} \\
\hline Mean \pm SD. (g/dl) & \multicolumn{2}{|l|}{$13.20 \pm 1.66$} & \multicolumn{2}{|l|}{$13.36 \pm 1.44$} & \\
\hline Median (g/dl) & \multicolumn{2}{|l|}{13.0} & \multicolumn{2}{|l|}{13.25} & \\
\hline \multicolumn{6}{|l|}{ S.creatinine } \\
\hline Min.-Max. (mg/dl) & \multicolumn{2}{|l|}{$0.60-3.20$} & \multicolumn{2}{|l|}{$0.60-1.70$} & \multirow[t]{3}{*}{$\mathrm{MW}_{p=0.857}$} \\
\hline Mean \pm SD. (mg/dl) & \multicolumn{2}{|l|}{$1.03 \pm 0.50$} & \multicolumn{2}{|l|}{$0.95 \pm 0.23$} & \\
\hline Median (mg/dl) & \multicolumn{2}{|l|}{0.90} & \multicolumn{2}{|l|}{0.95} & \\
\hline \multicolumn{6}{|l|}{ CKMB } \\
\hline Median (ng/ml) & \multicolumn{2}{|l|}{92.0000} & \multicolumn{2}{|l|}{35.0000} & ${ }^{*} p=<0.001$ \\
\hline$($ Min-max) (ng/ml) & \multicolumn{2}{|l|}{$(5.0-125)$} & \multicolumn{2}{|l|}{$(5.5-116)$} & \\
\hline \multicolumn{6}{|l|}{ Troponin } \\
\hline Median(ng/ml) & \multicolumn{2}{|l|}{7.5000} & \multicolumn{2}{|l|}{1.5000} & ${ }^{*} p=<0.001$ \\
\hline (Min-Max) (ng/ml) & \multicolumn{2}{|l|}{$(0.5-35)$} & \multicolumn{2}{|l|}{$(0.5-45)$} & \\
\hline $\mathrm{ECHO}$ & & & & & \\
\hline $\mathrm{EF}$ & & & & & \\
\hline Min-Max (\%) & $35-75$ & & $30-70$ & & $p=0.344$ \\
\hline Mean \pm SD (\%) & $58.64 \pm 7.44$ & & $59.19 \pm 7.616$ & & \\
\hline Median (\%) & 60 & & 60 & & \\
\hline RWMAS & 52 & $46.4 \%$ & 140 & $36.1 \%$ & $p=0.16$ \\
\hline Mitral regurgitation & & & & & \\
\hline No & 92 & $82.1 \%$ & 310 & $79.9 \%$ & $\mathrm{MW}_{p=0.492}$ \\
\hline Mild & 20 & $17.9 \%$ & 62 & $16 \%$ & \\
\hline Moderate & 0 & $0 \%$ & 12 & $3.1 \%$ & \\
\hline Severe & 0 & $0 \%$ & 4 & $1.5 \%$ & \\
\hline
\end{tabular}

$x^{2}$ value for Chi square, $t$ Student $t$-test, MW Mann-Whitney test

*Statistically significant at $p \leq 0.05$ 
Table 3 GRACE risk score and TIMI risk score at admission of the studied population

\begin{tabular}{|c|c|c|c|c|c|c|}
\hline & \multicolumn{2}{|c|}{ Group $1(n=112)$} & \multicolumn{2}{|c|}{ Group2 $(n=388)$} & \multirow{2}{*}{$\begin{array}{l}\text { Test of } \\
\text { significance }\end{array}$} & \multirow[t]{2}{*}{$p$} \\
\hline & No. & $\%$ & No. & $\%$ & & \\
\hline \multicolumn{7}{|l|}{ GRACE risk score [19] } \\
\hline Low (1-108) & 64 & 57.3 & 232 & 59.8 & $x^{2}=2.67$ & ${ }^{\mathrm{MC}} \boldsymbol{p}=0.28$ \\
\hline Intermediate (109-140) & 40 & 35.7 & 114 & 31.9 & & \\
\hline High (141-372) & 8 & 7 & 32 & 8.3 & & \\
\hline \multicolumn{7}{|l|}{ TIMI risk score [20] } \\
\hline Low (0-2) & 20 & 17.8 & 80 & 20.6 & $x^{2}=1.567$ & ${ }^{\mathrm{MC}} \boldsymbol{p}=0.37$ \\
\hline Intermediate (3-5) & 82 & 73.3 & 268 & 69.1 & & \\
\hline High $(>5)$ & 10 & 8.9 & 40 & 10.3 & & \\
\hline
\end{tabular}

$x^{2}$ value for Chi square, MC Monte Carlo test

*Statistically significant at $p \leq 0.05$

\section{Procedural characteristics of the studied population}

With regard to the angiographic data, the incidence of multivessel disease was not different between the two groups; group 1 patients had significantly higher percentages of LCX and RCA as the culprit vessel (55.4\% and 23.2\%), while group 2 patients had significantly higher percentages of LAD as the culprit vessel (53.1\%). This was statistically significant $p<0.001$. Also, there was no significant difference between the two groups regarding the baseline syntax score $(11.68 \pm 6.05$ vs. $6.79 \pm$ $3.24, p=0.12)$ or the residual syntax score $(1.27 \pm 2.67$ vs. $0.66 \pm 2.35, p=0.07)$. The presence of collaterals was significantly higher in group 1 than in group 2 (73.2\% vs. $4.6 \%, p<0.01)$.

All patients in the two groups were done through transfemoral approach and received drug-eluting stents (DES), and no patient had procedure-related complications. Also, the antiplatelet treatment with clopidogrel or ticagrelor did not differ, but the use of GP IIb/IIIa inhibitors was significantly higher in group 1 ( $23 \%$ vs. $3 \%, p=$ $0.04)$. All data of the procedural characteristics of the studied population are summarized in Table 4.

\section{In-hospital outcomes}

Group 1 patients showed higher risk of cumulative MACCE than group 2 (5.3\% versus $1 \%)$, but this was not statistically significant $(p=0.07)$. Two patients in each group died while in-hospital mostly because of arrhythmia (ventricular fibrillation). The need for revascularization and the incidence of heart failure, reinfarction, ischemic cerebrovascular stroke (CVS), or bleeding were not different between groups. In-hospital arrhythmia was significantly higher in group 1 compared to group $2(8.9 \%$ vs. $1 \%, p=0.007)$. The data of inhospital outcomes are summarized in Table 5.

\section{Six months follow-up}

The mean follow-up in our study was $215 \pm 29.5$ days. There was no significant difference between the two
Table 4 Procedural characteristics of the studied population

\begin{tabular}{|c|c|c|c|c|c|}
\hline & \multicolumn{2}{|c|}{$\begin{array}{l}\text { Group } 1 \\
(n=112)\end{array}$} & \multicolumn{2}{|c|}{$\begin{array}{l}\text { Group 2 } \\
(n=388)\end{array}$} & $p$ value \\
\hline \multicolumn{6}{|l|}{ Number of diseased vessels } \\
\hline One vessel CAD & 32 & $28.6 \%$ & 160 & $41.2 \%$ & $x 2 p=0.218$ \\
\hline Two vessel CAD & 52 & $46.4 \%$ & 154 & $39.7 \%$ & \\
\hline Three vessel CAD & 28 & $25 \%$ & 74 & $19.1 \%$ & \\
\hline \multicolumn{6}{|l|}{ Culprit vessel } \\
\hline LAD & 24 & $21.4 \%$ & 206 & $53.1 \%$ & $X 2 p=<0.001$ \\
\hline LCX & 62 & $55.4 \%$ & 154 & $25.8 \%$ & \\
\hline RCA & 26 & $23.2 \%$ & 74 & $21.1 \%$ & \\
\hline \multicolumn{6}{|l|}{ Site of the lesion } \\
\hline Proximal & 28 & $50 \%$ & 95 & $48.9 \%$ & $x 2 p=0.23$ \\
\hline Mid & 20 & $35.7 \%$ & 74 & $37.2 \%$ & \\
\hline Distal & 8 & $14.3 \%$ & 25 & $13.9 \%$ & \\
\hline \multicolumn{6}{|l|}{ TIMI pre procedure } \\
\hline 0 & 112 & $100 \%$ & 0 & $0 \%$ & $X 2 p=<0.001$ \\
\hline । & 0 & $0 \%$ & 0 & $0 \%$ & \\
\hline$\|$ & 0 & $0 \%$ & 64 & $16.5 \%$ & \\
\hline III & 0 & $0 \%$ & 324 & $83.5 \%$ & \\
\hline Use of GP IIa-IIIb antagonists & 26 & $23 \%$ & 14 & 3 & $p=0.04$ \\
\hline Collaterals & 82 & $73.2 \%$ & 18 & $4.6 \%$ & $X 2 p=<0.01$ \\
\hline TIMI III post procedure & 110 & $98.2 \%$ & 384 & $98.9 \%$ & $p=0.36$ \\
\hline \multicolumn{6}{|l|}{ Syntax score } \\
\hline Mean \pm SD & \multicolumn{2}{|c|}{$11.68 \pm 6.05$} & \multicolumn{2}{|c|}{$6.79 \pm 3.24$} & $M W p=0.12$ \\
\hline Median & \multicolumn{2}{|l|}{10} & \multicolumn{2}{|l|}{7.0} & \\
\hline Min-Max & \multicolumn{2}{|c|}{$4.0-24.0$} & \multicolumn{2}{|c|}{$4.0-22.0$} & \\
\hline \multicolumn{6}{|l|}{ Residual syntax score } \\
\hline Mean \pm SD & \multicolumn{2}{|c|}{$1.27 \pm 2.67$} & \multicolumn{2}{|c|}{$0.66 \pm 2.35$} & $M W p=0.07$ \\
\hline Median & \multicolumn{2}{|l|}{0} & \multicolumn{2}{|l|}{0} & \\
\hline Min-Max & \multicolumn{2}{|l|}{$0-15$} & \multicolumn{2}{|c|}{$0-20$} & \\
\hline
\end{tabular}

$x^{2}$ value for Chi square, $M W$ Mann-Whitney test

*Statistically significant at $p \leq 0.05$ 
Table $\mathbf{5}$ In-hospital outcomes of the studied population

\begin{tabular}{|c|c|c|c|c|c|}
\hline & \multicolumn{2}{|c|}{ Group $1(n=112)$} & \multicolumn{2}{|c|}{ Group $2(n=388)$} & \multirow[t]{2}{*}{$p$} \\
\hline & No. & $\%$ & No. & $\%$ & \\
\hline Arrhythmias & 10 & 8.9 & 4 & 1 & ${ }^{*} \mathrm{FE} p=0.007$ \\
\hline$A F$ & 4 & 3.5 & 2 & 0.5 & \\
\hline VF & 6 & 5.4 & 2 & 0.5 & \\
\hline HF & 4 & 3.5 & 16 & 0.04 & $\mathrm{FE}_{p}=1$ \\
\hline Bleeding & 6 & 5.4 & 2 & 0.5 & $\mathrm{FE}_{p}=0.06$ \\
\hline Major & 2 & 1.8 & 0 & 0.0 & \\
\hline Minor & 4 & 3.6 & 2 & 0.5 & \\
\hline CIN & 8 & 7.1 & 20 & 5.1 & $\mathrm{FE}_{p}=0.34$ \\
\hline Local vascular complication & 10 & 8.9 & 16 & 4.1 & $\mathrm{FE}_{p}=0.22$ \\
\hline MACCE & 6 & 5.3 & 4 & 1.0 & $\mathrm{FE}_{p}=0.07$ \\
\hline Death & 2 & 1.8 & 2 & 0.01 & ${ }^{\mathrm{FE}} p=0.39$ \\
\hline Reinfarction & 0 & 0.0 & 0 & 0 & \\
\hline Repeated revascularization & 2 & 1.8 & 0 & 0 & $\mathrm{FE}_{p}=0.22$ \\
\hline Stroke & 2 & 1.8 & 1 & 0.01 & $\mathrm{FE}_{p}=0.39$ \\
\hline
\end{tabular}

${ }^{F E} p$ Fisher's exact significance

*Statistically significant at $p \leq 0.05$

groups regarding the composite MACCE endpoint after 6 months follow-up ( $5.4 \%$ vs. $4.6 \%, p=0.24)$. Two patients in group 1 and 6 patients in group 2 died during follow-up $(1.8 \%$ vs. $0.02 \%, p=1)$. The need for revascularization and the incidence of heart failure, re-infarction, ischemic cerebrovascular stroke (CVS), or bleeding were not different between groups. The data of 6 months follow-up outcomes are summarized in Table 6 and Fig. 1 .

\section{Discussion}

The presence of an occluded culprit artery in NSTEMI patients cannot be diagnosed based on the clinical or electrocardiographic findings. The rationale beyond the absence of characteristic ST-segment elevation despite totally occluded artery in NSTEMI patients is still not understood. The lack of sensitivity of standard 12-lead ECG to detect changes of total occlusion in the inferolateral distribution [23-25], the presence of good collaterals, acute total occlusion in a territory with dual blood supply, and chronic total occlusion misclassified as acute occlusion could be possible mechanisms [26].

The objective of this study was to evaluate the incidence and impact of totally occluded culprit artery on in-hospital and midterm follow-up outcomes of NSTE MI patients.

In our study, the incidence of totally occluded culprit in NSTEMI patients was $23 \%$ which was similar to previous studies that reported an incidence of 25\% [9-11].

The mean time from admission to PCI in the totally occluded culprit artery group in our study was $27.11 \pm$ $10.6 \mathrm{~h}$; this was similar to Kim et al. [13] but contradicted by Soon et al. [14] who reported longer time and Karwowski et al. [12] who reported shorter mean time of chest pain to angiography in totally occluded group.

Table 6 Six months follow-up outcomes of the studied population

\begin{tabular}{|c|c|c|c|c|c|}
\hline & \multicolumn{2}{|c|}{ Group $1(n=112)$} & \multicolumn{2}{|c|}{ Group $2(n=388)$} & \multirow[t]{2}{*}{$p$} \\
\hline & No. & $\%$ & No. & $\%$ & \\
\hline MACCE & 6 & 5.4 & 18 & 4.6 & $p=0.24$ \\
\hline Death & 2 & 1.8 & 6 & 0.02 & $\mathrm{FE}_{p}=1$ \\
\hline Reinfarction & 2 & 1.8 & 8 & 0.02 & $\mathrm{FE}_{p=1}$ \\
\hline Repeated revascularization & 2 & 1.8 & 4 & 0.01 & $\mathrm{FE}_{p=0.53}$ \\
\hline Major bleeding & 0 & 0 & 0 & 0 & \\
\hline Heart failure & 2 & 1.8 & 6 & 0.02 & $\mathrm{FE}_{p=1}$ \\
\hline Stroke & 0 & 0 & 0 & 0 & \\
\hline
\end{tabular}

${ }^{F E} p$ Fisher's exact significance

*Statistically significant at $p \leq 0.05$ 


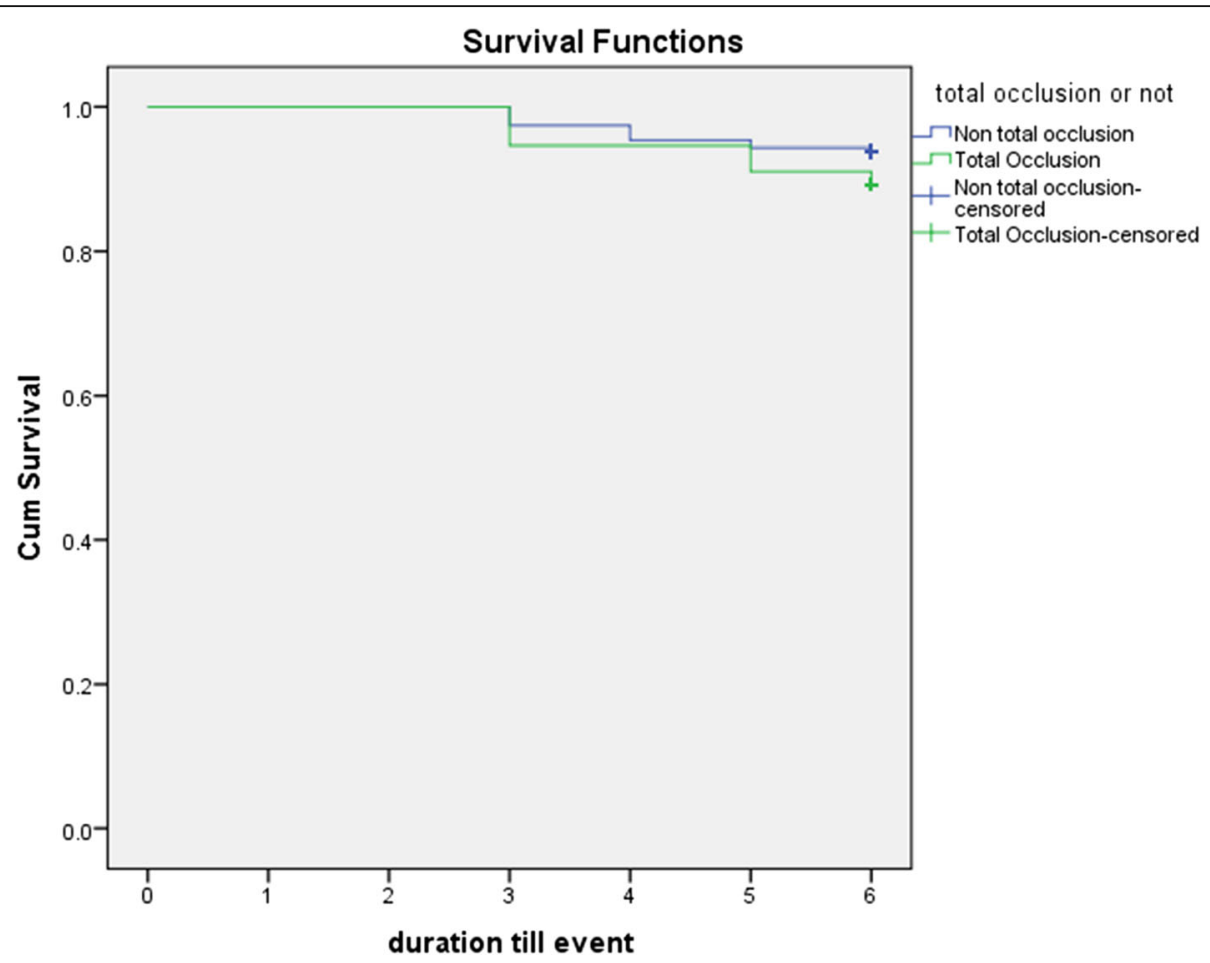

Fig. 1 Kaplan-Meier estimates of MACCE between the two groups at 6 months

In this study, the median of CKMB and troponin I levels was significantly higher in the totally occluded artery group $(p<0.001)$. This was similar to data from Karwowski et al. [12], Bahrmann et al. [11], and Wang et al. [10] that showed significantly higher CKMB and troponin levels in the totally occluded culprit artery populations.

There was no statistically significant difference in the mean left ventricular ejection fraction percentage (LVEF) between the two groups in our study $(58.64 \pm 7.44 \%$ vs $59.19 \pm 7.61 \%$; $p=0.34$ ), while Soon et al. [14] reported significantly lower EF in the totally occluded artery group.

Our study showed that in the totally occluded group, LCX represented the culprit vessel in $55.4 \%$ of patients, RCA was the culprit in $23.2 \%$, and LAD was the culprit in $21.4 \%$ of the patients. In non-totally occluded group, LAD represented the culprit vessel in $53.1 \%$ of patients, LCX was the culprit in $25.8 \%$, and RCA was the culprit in $21.1 \%$ of patients. This finding is compatible with other trials. Karwowski et al. [12] reported that in the totally occluded group, LCX represented the culprit vessel in $48.1 \%$ of patients and RCA in $29.5 \%$ of the patients.

The incidence of MACCE either in-hospital or after six months follow-up was similar among both groups, but the incidence of in-hospital arrhythmia was significantly higher in the totally occluded group $(p=0.007)$. We do not have a clear explanation for that but we can hypothesize that patients were on full medical therapy (dual antiplatelets, high-intensity statins, beta blockers, and RAS blockers), and the difference in the residual syntax score was not significant.

These results are consistent with most studies addressing impact of totally occluded culprit artery in NSTEMI patients [8-14].

The current study was limited in several ways. Firstly, the current study was a retrospective, single-center study. Secondly, patients with contraindication to PCI were excluded from the study and finally the relatively small sample size.

\section{Conclusion}

$22.4 \%$ of NSTEMI patients have a totally occluded culprit artery. The presence of an occluded culprit artery did not significantly affect the clinical outcomes of NSTEMI patients either in-hospital or after 6 months follow-up but was associated with significantly higher incidence of in-hospital arrhythmia. Further studies with bigger sample size and longer follow-up duration are recommended.

\section{Abbreviations}

ACS: Acute coronary syndrome; CABG: Coronary artery bypass grafting; CKMB: Creatine kinase-MB isoenzyme; ECG: Electrocardiography; GRACE: Global Registry of Acute Coronary Events; LCx: Left circumflex artery; LVEF: Left ventricular ejection fraction; MI: Myocardial infarction; NSTEMI: Non-ST segment elevation acute coronary syndrome; STEMI: ST segment elevation myocardial infarction; PCl: Percutaneous coronary intervention; 
TIMI: Thrombolysis in myocardial infarction; MACCE: Major adverse cardiac and cerebrovascular events; CVS: Cerebrovascular stroke; RCA: Right coronary artery; LAD: Left anterior descending artery; CIN: Contrast-induced nephropathy; AF: Atrial fibrillation; VF: Ventricular fibrillation; CAD: Coronary artery disease; LM: Left main; Hb: Hemoglobin; DM: Diabetes mellitus; HTN: Hypertension; CKD: Chronic kidney disease; WMA: Wall motion abnormality

\section{Acknowledgements}

None.

\section{Authors' contributions}

SWA, THE, and MIL searched the literature, collected the data, performed the statistical analyses, and wrote the manuscript; SWA, AME, AMN, and THE contributed to conception, design, data interpretation, and supervision of the study. All authors read and approved the final manuscript.

\section{Funding}

No external funding was acquired for this research.

\section{Availability of data and materials}

All data analyzed during this research are included in this published article.

\section{Declarations}

\section{Ethics approval and consent to participate}

An informed written consent was obtained from every patient or the legal guardians. The study was approved by the Faculty of Medicine Alexandria University ethics committee. Approval number 0304894.

\section{Consent for publication}

Not applicable (no individual personal data are included in the study).

\section{Competing interests}

The authors declare that they have no competing interests.

Received: 30 October 2020 Accepted: 23 March 2021

\section{Published online: 07 April 2021}

\section{References}

1. Mozaffarian D, Benjamin EJ, Go AS, Arnett DK, Blaha MJ, Cushman M, Das SR, de Ferranti S, Despres JP, Fullerton HJ, Howard VJ, Huffman MD, Isasi CR, Jimenez MC, Judd SE, Kissela BM, Lichtman JH, Lisabeth LD, Liu S, Mackey RH, Magid DJ, McGuire DK, Mohler ER 3rd, Moy CS, Muntner P, Mussolino ME, Nasir K, Neumar RW, Nichol G, Palaniappan L, Pandey DK, Reeves MJ, Rodriguez CJ, Rosamond W, Sorlie PD, Stein J, Towfighi A, Turan TN, Virani SS, Woo D, Yeh RW, Turner MB, American Heart Association Statistics Committee, Stroke Statistics Subcommittee (2016) Executive summary: heart disease and stroke statistics-2016 update: a report from the American Heart Association. Circulation 133:447-454

2. Vedanthan R, Seligman B, Fuster V (2014) Global perspective on acute coronary syndrome: a burden on the young and poor. Circ Res 114(12): 1959-1975. https://doi.org/10.1161/CIRCRESAHA.114.302782

3. Taylor MJ, Scuffham PA, McCollam PL, Newby DE (2007) Acute coronary syndromes in Europe: 1-year costs and outcomes. Curr Med Res Opin 23(3): 495-503. https://doi.org/10.1185/030079906X167462

4. Access Investigators (2011) Management of acute coronary syndromes in developing countries: acute coronary events-a multinational survey of current management strategies. Am Heart J 162(5):852-9.

5. Vieira M, Dinis P, Reis L, Madeira M, Ribeiro J, Fernandes A et al (2017) Inhospital mortality in STEMI and NSTEMI: are they so different? Eur J Heart Fail 19:157

6. O'Gara PT, Kushner FG, Ascheim DD, Casey DE Jr, Chung MK, de Lemos JA, Ettinger SM, Fang JC, Fesmire FM, Franklin BA, Granger CB, Krumholz HM, Linderbaum JA, Morrow DA, Newby LK, Ornato JP, Ou N, Radford MJ, TamisHolland JE, Tommaso JE, Tracy CM, Woo YJ, Zhao DX (2013) 2013 ACCF/ AHA guideline for the management of ST-elevation myocardial infarction: executive summary: a report of the American College of Cardiology Foundation/American Heart Association Task Force on Practice Guidelines. Circulation 127(4):529-555. https://doi.org/10.1161/CIR.0b013e3182742c84
7. Amsterdam EA, Wenger NK, Brindis RG, Casey DE Jr, Ganiats TG, Holmes DR Jr, Jaffe AS, Jneid H, Kelly RF, Kontos MC, Levine GN, Liebson PR, Mukherjee D, Peterson ED, Sabatine MS, Smalling RW, Zieman SJ (2014) 2014 AHA/ACC guideline for the management of patients with non-ST-elevation acute coronary syndromes: a report of the American College of Cardiology/ American Heart Association Task Force on Practice Guidelines. J Am Coll Cardiol 64(24):e139-e228. https://doi.org/10.1016/j.jacc.2014.09.017

8. Warren J, Mehran R, Yu J, Xu K, Bertrand ME, Cox DA, Lincoff AM, Manoukian SV, Ohman EM, Pocock SJ, White HD, Stone GW (2015) Incidence and impact of totally occluded culprit coronary arteries in patients presenting with non-ST-segment elevation myocardial infarction. Am J Cardiol 115(4):428-433. https://doi.org/10.1016/j.amjcard.2014.11.023

9. Shin Dl, Chang K, Ahn Y, Hwang BH, Park HJ, Seo SM et al (2014) Impact of occluded culprit arteries on long-term clinical outcome in patients with non-ST-elevation myocardial infarction: 48-month follow-up results in the COREA-AMI Registry. J Interv Cardiol 27(1):12-20. https://doi.org/10.1111/ joic. 12078

10. Wang TY, Zhang M, Fu Y, Armstrong PW, Newby LK, Gibson CM, Moliterno DJ, van de Werf F, White HD, Harrington RA, Roe MT (2009) Incidence, distribution, and prognostic impact of occluded culprit arteries among patients with non-ST-elevation acute coronary syndromes undergoing diagnostic angiography. Am Heart J 157(4):716-723. https://doi.org/10.1016/ j.ahj.2009.01.004

11. Bahrmann P, Rach J, Desch S, Schuler GC, Thiele H (2011) Incidence and distribution of occluded culprit arteries and impact of coronary collaterals on outcome in patients with non-ST-segment elevation myocardial infarction and early invasive treatment strategy. Clin Res Cardiol 100(5):457467. https://doi.org/10.1007/s00392-010-0269-9

12. Karwowski J, Poloński L, Gierlotka M, Ciszewski A, Hawranek M, Bęćkowski M et al (2017) Total coronary occlusion of infarct-related arteries in patients with non-ST-elevation myocardial infarction undergoing percutaneous coronary revascularisation. Kardiol Pol 75(2):108-116

13. Kim MC, Ahn Y, Rhew SH, Jeong MH, Kim JH, Hong YJ, Chae SC, Kim YJ, Hur SH, Seong IW, Chae JK, KAMIR Investigators (2012) Impact of total occlusion of an infarct-related artery on long-term mortality in acute non-ST-elevation myocardial infarction patients who underwent early percutaneous coronary intervention. Int Heart J 53(3):160-164. https://doi.org/10.1536/ihj.53.160

14. Soon K, Du HN, Klim S, Zakariyya A, Kelly AM (2014) Non-ST elevation myocardial infarction with occluded artery and its clinical implications. Heart Lung Circ 23(12):1132-1140. https://doi.org/10.1016/j.hlc.2014.05.014

15. Menon V, Ruzyllo W, Carvalho AC, Almeida de Sousa JM, Forman SA, Jaworska K, Lamas GA, Roik M, Thuaire C, Turgeman Y, Hochman JS (2013) Infarct artery distribution and clinical outcomes in occluded artery trial subjects presenting with non-ST-segment elevation myocardial infarction (from the long-term follow-up of Occluded Artery Trial [OAT]). Am J Cardiol 111(7):930-935. https://doi.org/10.1016/j.amjcard.2012.12.009

16. Dixon WC, Wang TY, Dai D, Shunk KA, Peterson ED, Roe MT, National Cardiovascular Data R (2008) Anatomic distribution of the culprit lesion in patients with non-ST-segment elevation myocardial infarction undergoing percutaneous coronary intervention: findings from the National Cardiovascular Data Registry. J Am Coll Cardiol 52(16):1347-1348. https:// doi.org/10.1016/j.jacc.2008.07.029

17. Pride YB, Tung P, Mohanavelu S, Zorkun C, Wiviott SD, Antman EM, Giugliano R, Braunwald E, Gibson CM, Group TS (2010) Angiographic and clinical outcomes among patients with acute coronary syndromes presenting with isolated anterior ST-segment depression: a TRITON-TIMI 38 (Trial to Assess Improvement in Therapeutic Outcomes by Optimizing Platelet Inhibition With Prasugrel-Thrombolysis In Myocardial Infarction 38) substudy. J Am Coll Cardiol Intv 3(8):806-811

18. TIMI Study Group (1989) Comparison of invasive and conservative strategies after treatment with intravenous tissue plasminogen activator in acute myocardial infarction. Results of the thrombolysis in myocardial infarction (TIMI) phase II trial. N Eng J Med 320:618-627

19. Tang EW, Wong CK, Herbison P (2007) Global Registry of Acute Coronary Events (GRACE) hospital discharge risk score accurately predicts long-term mortality post acute coronary syndrome. Am Heart J 153(1):29-35. https:// doi.org/10.1016/j.ahj.2006.10.004

20. Huynh T, Nasmith J, Luong TM, Bernier M, Pharand C, Xue-Qiao Z et al (2009) Complementary prognostic values of ST segment deviation and thrombolysis in myocardial infarction (TIMI) risk score in non-ST elevation acute coronary syndromes: insights from the Platelet Receptor Inhibition in 
Ischemic Syndrome Management in Patients Limited by Unstable Signs and Symptoms (PRISM-PLUS) study. Can J Cardiol 25(12):e417-ee21

21. Papadopoulou SL, Girasis C, Dharampal A, Farooq V, Onuma Y, Rossi A et al (2013) CT-SYNTAX score. JACC Cardiovasc Imaging 6(3):413-415

22. Kirkpatrick LA, Feeney BC (2013) A simple guide to IBM SPSS statisticsfor version 20.0. Student ed. Wadsworth, Cengage Learning, Belmont

23. Wong CK, White HD (2012) Patients with circumflex occlusions miss out on reperfusion: how to recognize and manage them. Curr Opin Cardiol 27(4): 327-330. https://doi.org/10.1097/HCO.0b013e32835482b7

24. Wagner G, Lim T, Gettes L, Gorgels A, Josephson M, Wellens H, Anderson S, Childers R, Clemmensen P, Kligfield P, Macfarlane P, Pahlm O, Selvester R (2006) Consideration of pitfalls in and omissions from the current ECG standards for diagnosis of myocardial ischemia/infarction in patients who have acute coronary syndromes. Cardiol Clin 24(3):331-342. https://doi.org/1 0.1016/j.ccl.2006.04.012

25. Menon V, Ruzyllo W, Carvalho AC, Marconi J, de Sousa A, Forman SA et al (2013) Infarct artery distribution and clinical outcomes in occluded artery trial subjects presenting with non ST elevation myocardial infarction (from the long term follow-up of the occluded artery trial). Am J Cardiol 111(7): 930-935. https://doi.org/10.1016/j.amjcard.2012.12.009

26. Kalaycı B, Sayin MR (2016) A rare cause of non-ST elevation myocardial infarction related to total coronary artery occlusion: dual RCA. Int J Cardiovasc Acad 2(3):134-136. https://doi.org/10.1016/j.ijcac.2016.06.007

\section{Publisher's Note}

Springer Nature remains neutral with regard to jurisdictional claims in published maps and institutional affiliations.

\section{Submit your manuscript to a SpringerOpen ${ }^{\circ}$ journal and benefit from:}

- Convenient online submission

- Rigorous peer review

- Open access: articles freely available online

High visibility within the field

- Retaining the copyright to your article

Submit your next manuscript at $\boldsymbol{\nabla}$ springeropen.com 